\title{
COMPARISON OF DTPA AND RESIN EXTRACTABLE SOIL ZN TO PLANT ZN UPTAKE
}

\section{A. Hamilton and D. T. Westermann}

USDA-ARS Soil and Water Management Research Center, Kimberly, Idaho 83341

ABSTRACT: Extraction of soil zinc with routine chemical extractants does not always reflect differences in $\mathrm{Zn}$ availability as detected by plant uptake. This study was undertaken to explore and compare the use of an ion exchange resin and diethylenetriaminepentaacetic acid (DTPA) for extracting soil $\mathrm{Zn}$ as related to plant $\mathrm{Zn}$ uptake. Beans were grown in 1989 following differential cropping with corn and beans or fallow in 1988 on a Portneuf silt loam near Kimberly, Idaho. Two $\mathrm{Zn}$ fertilizer treatments were imposed across previous cropping treatments. A batch method for determining resin extractable soil $\mathrm{Zn}$ was established.

Both plant $\mathrm{Zn}$ concentration and $\mathrm{Zn}$ uptake by beans in 1989 were significantly higher in $\mathrm{Zn}$ fertilized than unfertilized treatments regardless of previous crop; and higher in plots previously cropped with corn than beans or fallow, regardless of $\mathrm{Zn}$ treatment. DTPA and resin extractable soil $\mathrm{Zn}$ were significantly higher in $\mathrm{Zn}$ fertilized plots compared to unfertilized plots but did not differ between previous cropping treatments. Resin and DTPA extractable soil $\mathrm{Zn}$ concentrations were positively correlated. Resin extracted soil $\mathrm{Zn}$ correlated better with plant $\mathrm{Zn}$ concentration and $\mathrm{Zn}$ uptake throughout the growing season than DTPA extracted soil $\mathrm{Zn}$, particularly in plots that had been fallowed or previously cropped with corn. Resin may be extracting labile soil Zn not extracted with DTPA and, therefore, be better simulating plant uptake. Both extraction methods correlated better with $\mathrm{Zn}$ uptake when evaluated within cropping treatments, emphasizing the need to consider previous crop when calibrating soil tests.

\section{INTRODUCTION}

Soil testing for micronutrient cations such as $\mathrm{Zn}$ is often difficult because plant 
requirements are relatively low. Soil solution concentrations are usually low as well and contamination problems are common. Chemical analysis of plant tissues for micronutrients and calibration of the results with response to fertilizers may be superior to soil tests but can be time consuming and costly. Plant analysis is also of little use in predicting fertilizer needs before the crops are planted. A soil test is essential for predicting yield responses prior to planting.

Extractants commonly used to determine soil $\mathrm{Zn}$ concentrations include acids such as $0.1 \mathrm{~N} \mathrm{HCl}$, which is used extensively and has the most calibration work, and synthetic chelating agents such as DTPA, EDTA, and dithizone. Viets and Lindsay (1) suggest that a satisfactory soil test should: a) extract nutrients from the same labile nutrient pool in the soil that plants do; and b) be cheap, be reproducible by different laboratories, and be easily adaptable to routine lab procedures.

It was shown, however, that chemically extracted soil $\mathrm{Zn}$ does not always correlate with $\mathrm{Zn}$ uptake by plants. Bauer and Lindsay (2), using short term uptake, demonstrated an increase in available $\mathrm{Zn}$ to corn plants after incubating soil at $43^{\circ} \mathrm{C}$ for 1 to 3 weeks. The temperature-released $\mathrm{Zn}$ was not detected by chemical soil extractants. Leggett and Westermann (3) demonstrated differences in $\mathrm{Zn}$ concentration and uptake by beans depending on the previous crop which was not detected with DTPA extractable soil $\mathrm{Zn}$ tests. An alternative soil test for $\mathrm{Zn}$ that better reflects $\mathrm{Zn}$ availability as detected by plant uptake would be useful in such situations.

Synthetic ion exchange resins were used to extract ions from the soil, particularly $P(4,5,6,7)$ and $N(8,9,10)$. Use of resins for extracting soil $K$ has also been investigated (11). However, little work has been done using ion exchange resins for extracting soil $\mathrm{Zn}$. Salomon and Smith (11) found that use of exchange resin appeared to be more effective in estimating crop response to $\mathrm{K}$ fertilizer than buffered acetate solutions. Moser et al. (7) concluded that an ion exchange resin method of estimating soil $\mathrm{P}$ concentration demonstrated greater precision in predicting $P$ uptake than routine chemical extractants. The purpose of this study was to compare ion exchange resin and DTPA for determining soil $\mathrm{Zn}$ concentrations as related to $\mathrm{Zn}$ uptake by plants.

\section{METHODS AND MATERIALS}

An experiment was conducted on a Portneuf silt loam (coarse silty, mixed, 
mesic, Durixerollic Calciorthid) at the Snake River Conservation Research Center near Kimberly, ID. A field was differentially cropped with bean (Phaseolus vulgaris L.) and corn (Zea mays L.) or fallowed in 1988. At harvest, whole plant tops were removed from the corn plots. Bean seed was separated from the plants and removed from the plots. An application of $11 \mathrm{~kg} \mathrm{Zn} / \mathrm{ha}$ as $\mathrm{ZnSO} 4$ was made to half of each plot in a randomized split plot design in the fall of 1988 . Soil samples $(0-30 \mathrm{~cm})$ were taken from each split plot in the spring of 1989 . Each sample was air dried, and ground in a stainless steel mill to pass a 2-mm sieve. Viva dry bean variety was planted $(56 \mathrm{~cm}$ spacing) in 1989 . During both the differentially cropped year and the test crop year, plots were row irrigated. All plots were irrigated for the same length of time. Whole bean plant tops were sampled periodically throughout the growing season, washed with distilled water, dried in forced air ovens $\left(60^{\circ} \mathrm{C}\right)$, and ground in a stainless steel mill to pass through a $0.6-\mathrm{mm}$ sieve. The plant samples were digested with perchloric and nitric acids, and $\mathrm{Zn}$ concentration was determined with an atomic absorption spectrophotometer (A.A.).

The DTPA extractable Zn was determined for each soil sample (12). Subsamples of the remaining soil samples were extractedwith the heavy metal, cation exchange, Chelex 100 resin (Na-form) using a batch method. Moist resin was prepared by mixing with two bed volumes of $50 \% \mathrm{NaOH}$ and heated to $60^{\circ} \mathrm{C}$ for 24 hours to insure complete regeneration to the $\mathrm{Na}$-form. The resin was then rinsed with five bed volumes of deionized, distilled water to remove interstitial $\mathrm{NaOH}$. The CEC of the $\mathrm{Na}$-form resin is $0.7 \mathrm{meq} / \mathrm{mL}$ (defined as $\mathrm{Cu}\left(\mathrm{NH}_{3}\right) 4^{+2}$ uptake) (13).

Several trials were run initially on all the soil samples, using duplicate sets to determine the appropriate soil/resin ratio and to assess the reproducibility of results. A trial using replicates of one sample was run to determine the extraction time necessary to reach maximum $\mathrm{Zn}$ extraction by the resin. Two replicates were removed and analyzed at $24 \mathrm{hr}$ intervals. The following procedure was established and conducted on all soil samples.

A $20 \mathrm{~g}$ sample of air dry soil was weighed into $150 \mathrm{~mL}$, acid washed, polyethylene bottles. A $23 \mathrm{~mL}$ volume of moist resin was added with a premeasured, plastic scoop. A portion of the resin CEC (5\%) was loaded with $\mathrm{HgCl} 2$ to prevent biological growth (13). A $50 \mathrm{~mL}$ volume of deionized, distilled water was added to each bottle. The bottles were capped and placed on a shaker at $21^{\circ} \mathrm{C}$ 
for one week. The solution with resin was then rinsed onto a stainless steel sieve $(0.18 \mathrm{~mm})$ and rinsed with a stream of deionized, distilled water until all visible soil and debris was gone. The resin was then transferred into a $100 \mathrm{~mL}$ volumetric flask and filled to volume with $1 \mathrm{~N} \mathrm{HCl}$, to extract $\mathrm{Zn}$ from the resin. The resin was left in the acid for $1.5 \mathrm{hr}$ with periodic swirling. Previous trials indicated no further removal of resin $\mathrm{Zn}$ after $1 \mathrm{hr}$ in acid. Zinc concentration of the acid solutions was then determined. The volume of the $1 \mathrm{~N} \mathrm{HCl}$ solution was corrected for the volume occupied by the resin in all calculations. While this batch technique of ion removal is considered less efficient than column exchange, it is fast, easy, and large sample sets can be run routinely. Standard $\mathrm{Zn}$ solutions were mixed with resin and treated in the same manner as the soil solutions. Percent recovery from the standard solutions was used to correct soil sample results, thereby adjusting for any loss of efficiency resulting from this batch method.

\section{RESULTS}

Resin Exchange Method: Initial trials were run using $4 \mathrm{~g}$ of air dry soil. A 50 to $100 \mathrm{~mL}$ volume of acid was needed to satisfactorily rinse the resin into a flask and provide enough solution volume to insure contact between acid and resin when swirling flasks. This produced a final solution with $\mathrm{Zn}$ concentrations too low to be detected with A.A. In subsequent trials, it was established that $20 \mathrm{~g}$ of air dry soil were necessary to obtain high enough $\mathrm{Zn}$ concentrations in the final solutions to detect differences with A.A. Based on average soil $\mathrm{Zn}$ concentrations as determined with DTPA, it was calculated that $20 \mathrm{~mL}$ of moist Chelex 100 resin (Naform) would provide an excess exchange capacity for the $20 \mathrm{~g}$ sample of soil. Means were not significantly different between duplicates. There was no appreciable change in $\mathrm{Zn}$ concentration with continued shaking beyond $96 \mathrm{hr}$ (Fig. 1). Mean $\mathrm{Zn}$ recovery by resin for standard $\mathrm{Zn}$ solutions extracted concurrently with the soil samples was $75 \%$. Resin extractable soil $\mathrm{Zn}$ concentrations reported were corrected for standard recovery using this figure.

Comparison of Resin and DTPA Extraction: The precropping and $\mathrm{Zn}$ fertilizer treatments used in this experiment provided a range of soil $\mathrm{Zn}$ concentrations over which to compare extraction methods. Treatment means for the main effects of previous crop and $\mathrm{Zn}$ fertilization for both extraction methods are presented in Table 1 . Means were not significantly different between extraction 


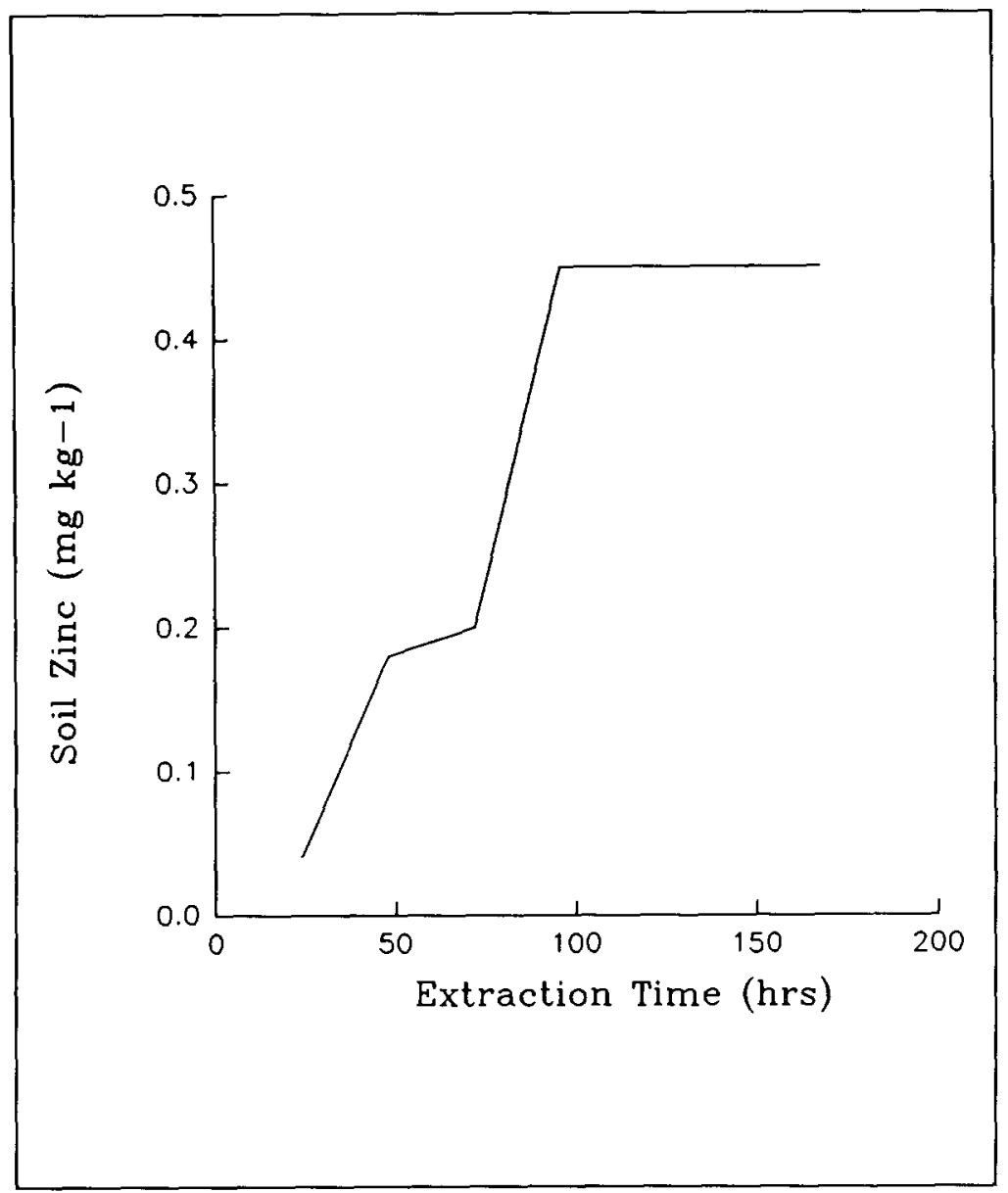

FIGURE 1. Effect of Shaking Time on Soil Zinc Extracted With Resin

methods. Results from the two extraction methods were positively correlated (Fig. 2). These results suggest that DTPA and resin are extracting $\mathrm{Zn}$ from similar soil $\mathrm{Zn}$ pools. For this soil type and range of soil $\mathrm{Zn}$ concentrations, both methods provided similar estimates of available soil $\mathrm{Zn}$. 
TABLE 1. Treatment Effects on DTPA and Resin Extractable Soil Zinc Concentrations

\begin{tabular}{|c|c|c|c|}
\hline & DTPA & $\begin{array}{l}\text { Extractable } \\
\text { Soil } \mathrm{Zn}\end{array}$ & $\begin{array}{c}\text { Resin Extractable } \\
\text { Soil } \mathrm{Zn}\end{array}$ \\
\hline TREATMENT & \multicolumn{3}{|c|}{$\mathrm{mg} \mathrm{kg}^{-1}$} \\
\hline \multicolumn{4}{|l|}{ Previous crop } \\
\hline Corn & & $0.69 \mathrm{a}$ & $0.70 \mathrm{a}$ \\
\hline Beans & & 0.69 a & 0.72 a \\
\hline Fallow & & $0.80 \mathrm{a}$ & 0.78 a \\
\hline \multicolumn{4}{|c|}{ Zn fertilizer } \\
\hline +Zinc & & $0.89 \mathrm{~b}$ & $0.92 \mathrm{~b}$ \\
\hline -Zinc & & $0.56 \mathrm{a}$ & $0.54 \mathrm{a}$ \\
\hline \multicolumn{4}{|c|}{ ANOVA probabilities } \\
\hline Crop & & $p=.37$ & $p=.69$ \\
\hline Zinc & & $p=.01$ & $p=.00$ \\
\hline Crop $\mathrm{x}$ Zinc & & $\mathrm{p}=.80$ & $p=.86$ \\
\hline
\end{tabular}

* Treatment means with similar letters within columns and treatments are not significantly different at the 0.05 level based on LSD multiple comparisons.

Zinc concentration and uptake at four stages of bean plant development indicated a difference in $\mathrm{Zn}$ availability due to both precropping treatment and $\mathrm{Zn}$ fertilizer treatment (Table 2 ). In comparison to plants from plots previously cropped with bean, plant $\mathrm{Zn}$ uptake was higher in plots previously cropped with corn, and lower in plots previously fallowed. Plant $\mathrm{Zn}$ concentration and uptake were consistently greater in $\mathrm{Zn}$ fertilized plots compared to unfertilized plots. Soil $\mathrm{Zn}$ concentrations, however, were only significantly different between $\mathrm{Zn}$ fertilized and unfertilized treatments, regardless of extraction method (Table 1). There were no significant differences in soil $\mathrm{Zn}$ concentration between precropping treatments.

Correlation coefficients between soil $\mathrm{Zn}$ concentration and plant $\mathrm{Zn}$ concentration were higher for resin-Zn extraction (0.30, 0.28, 0.29, and 0.32 for 6/19/89, 


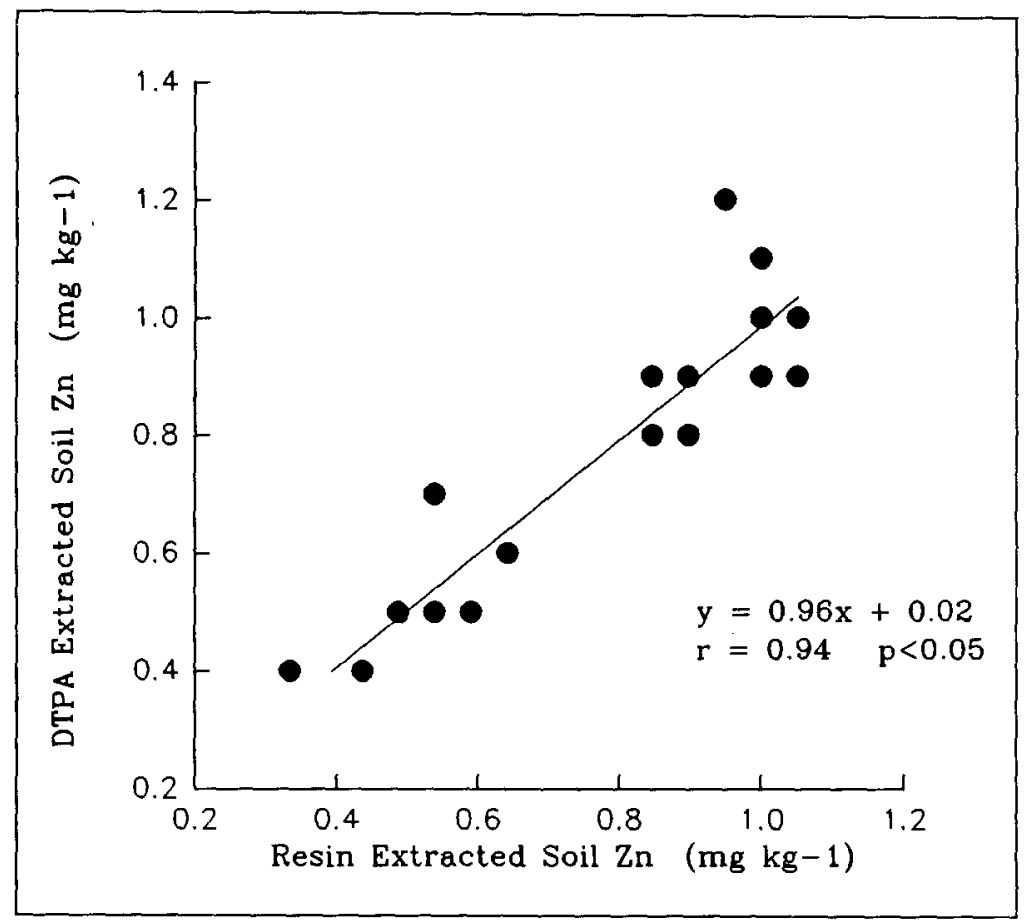

FIGURE 2. Resin vs DTPA Extractable Soil Zinc

$6 / 30 / 89,7 / 10 / 89$, and 7/21/89, respectively) than for DTPA-Zn extraction $(0.19$, $0.21,0.20$, and 0.28 ). All correlation coefficients between resin extracted soil $\mathrm{Zn}$ and plant $\mathrm{Zn}$ concentrations were significant ( $\mathrm{p} \leq 0.05$ ), while none were between DTPA extracted soil $\mathrm{Zn}$ and plant $\mathrm{Zn}$ concentrations.

Correlation coefficients between soil $\mathrm{Zn}$ concentration and plant $\mathrm{Zn}$ uptake were also higher at all dates for resin extraction than for DTPA extraction. However, only the correlation coefficient for resin extracted soil $\mathrm{Zn}$ and $\mathrm{Zn}$ uptake at the earliest stage of plant growth $(6 / 19 / 89)$ was significant $(r=0.39, p<0.05)$. These results suggest that resin extraction better approximates $\mathrm{Zn}$ availability as detected by plants than DTPA. 


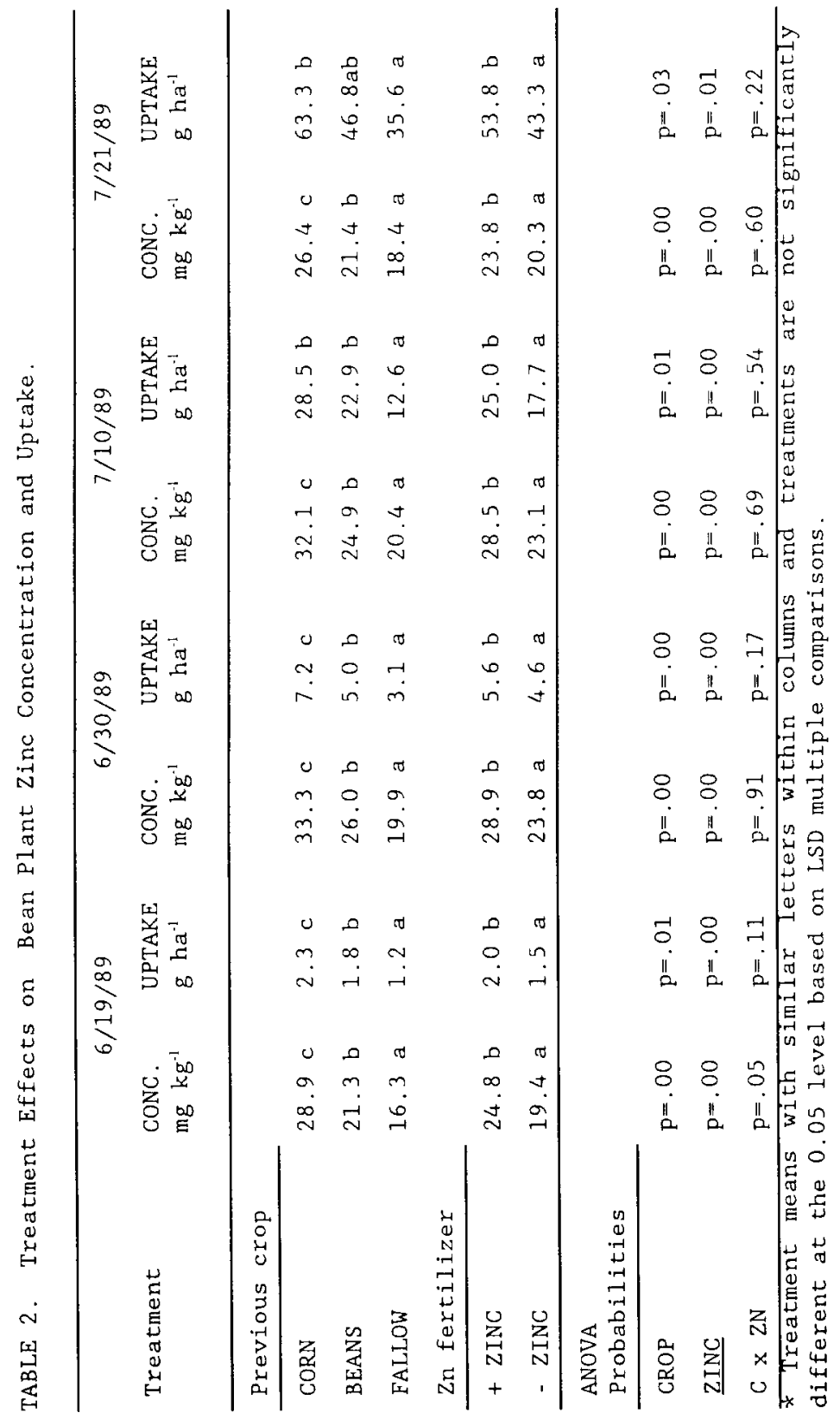


The data were evaluated within pre-cropping treatments. Within the corn and fallow treatments, the correlation coefficients associated with the prediction equations were higher using resin extractable soil $\mathrm{Zn}$ to predict $\mathrm{Zn}$ uptake than with DTPA extractable soil $\mathrm{Zn}$ (Table 3). Within bean treatments, there was little difference in correlation coefficients between resin and DTPA extractable soil $\mathrm{Zn}$. Slopes for the prediction equations were not significantly different between extraction methods for any precropping treatment. Within each precropping treatment, both methods of soil $\mathrm{Zn}$ extraction had higher correlation coefficients with Zn uptake than those obtained using the combined data, suggesting that soil tests are better predictors of $\mathrm{Zn}$ uptake when differential cropping is not a factor. Within both the $\mathrm{Zn}$ fertilized and unfertilized treatments, neither DTPA or resin extractable soil $\mathrm{Zn}$ concentration were correlated with plant $\mathrm{Zn}$ uptake.

\section{CONCLUSIONS}

The method described for using resin to extract soil $\mathrm{Zn}$ is easy, inexpensive, and can be done routinely. However, it does require lengthy extraction times when compared to DTPA extraction. For this particular soil, both methods gave similar results and were equally effective at detecting differences in soil $\mathrm{Zn}$ concentrations caused by $\mathrm{Zn}$ fertilization. Differences in $\mathrm{Zn}$ availability to the subsequent crop due to differential cropping were detected by plant uptake but not by DTPA or resin soil Zn extraction.

Following differential cropping, resin extractable soil $\mathrm{Zn}$ correlated better with plant $\mathrm{Zn}$ concentration and uptake than DTPA extractable $\mathrm{Zn}$. This improvement appears to be primarily from the increased correlation between resin soil $\mathrm{Zn}$ and $\mathrm{Zn}$ uptake following corn and fallow treatments. This emphasizes the influence of previous crop on $\mathrm{Zn}$ availability and on the soil test's ability to predict $\mathrm{Zn}$ availability. The increased correlation coefficients for both extraction methods when the data were evaluated within precropping treatments suggests the need to calibrate soil tests with consideration given to previous crop.

Resin and DTPA each extracted similar amounts of soil $\mathrm{Zn}$. However, the difference in correlations between soil $\mathrm{Zn}$ and $\mathrm{Zn}$ uptake suggests that resin extraction better simulates uptake by plant roots. The amount of chelated metal accumulating in solution during extraction is a function of both initial activity of the ion (intensity) and the ability of the soil to replenish the ions (capacity). As with the chelating agent, resin is expected to adsorb the readily available or exchangeable 
TABLE 3. Regressions Within Precropping Treatments: Soil $\mathrm{Zn}$ Concentration vs Plant Zn Uptake

\begin{tabular}{|c|c|c|c|c|}
\hline $\begin{array}{l}\text { Previous } \\
\text { crop }\end{array}$ & & $6 / 19 / 89$ & $6 / 30 / 89$ & $7 / 10 / 89$ \\
\hline \multirow[t]{2}{*}{ Fallow } & $\begin{array}{l}\text { DTPA Zn } \\
\text { vs }\end{array}$ & $r=0.73$ & $\mathrm{r}=0.48$ & $r=0.49$ \\
\hline & $\begin{array}{l}\text { Zn } \\
\text { uptake }\end{array}$ & $b=0.47$ & $b=1.25$ & $b=6.54$ \\
\hline \multirow[t]{2}{*}{ Fallow } & Resin & $r=0.85$ & $r=0.54$ & $r=0.57$ \\
\hline & $\begin{array}{l}\text { Zn } \\
\text { uptake }\end{array}$ & $b=0.64$ & $b=1.63$ & $b=8.91$ \\
\hline \multirow[t]{2}{*}{ Bean } & $\begin{array}{l}\text { DTPA Zn } \\
\text { vs }\end{array}$ & $\mathrm{r}=0.89$ & $r=0.93$ & $r=0.77$ \\
\hline & $\begin{array}{l}\text { Zn } \\
\text { uptake }\end{array}$ & $b=1.18$ & $b=3.75$ & $b=20.50$ \\
\hline \multirow[t]{2}{*}{ Bean } & Resin & $r=0.91$ & $r=0.93$ & $r=0.76$ \\
\hline & $\begin{array}{l}\mathrm{Zn} \text { vs } \\
\mathrm{Zn} \\
\text { uptake }\end{array}$ & $b=1.13$ & $b=3.54$ & $b=19.18$ \\
\hline \multirow[t]{2}{*}{ Corn } & $\begin{array}{l}\text { DTPA Zn } \\
\text { vs }\end{array}$ & $r=0.61$ & $r=0.38$ & $r=0.17$ \\
\hline & $\begin{array}{l}\mathrm{Zn} \\
\text { uptake }\end{array}$ & $b=1.62$ & $b=2.18$ & $b=5.04$ \\
\hline \multirow[t]{2}{*}{ Corn } & $\begin{array}{l}\text { Resin } \\
\text { Zn vs }\end{array}$ & $r=0.83$ & $r=0.48$ & $r=0.33$ \\
\hline & $\begin{array}{l}\mathrm{Zn} \\
\text { uptake }\end{array}$ & $b=1.99$ & $b=2.44$ & $\mathrm{~b}=8.63$ \\
\hline
\end{tabular}

soil $\mathrm{Zn}$, and to reflect both intensity and capacity factors. It is possible, however, that the lengthy extraction time with resin allows more removal of $\mathrm{Zn}$ from the strongly adsorbed and labile soil $\mathrm{Zn}$ pools that are available only upon removal of the readily exchangeable $\mathrm{Zn}$ from solution. DTPA, however,may be primarily extracting only from the soluble and readily exchangeable soil $\mathrm{Zn}$ pools. 
Further investigation of the use of ion exchange resin to determine $\mathrm{Zn}$ availability is needed. The method described here may require considerable revision under different conditions and with different soils. Investigation of the effect of previous crop on $\mathrm{Zn}$ availability and on soil test calibration with $\mathrm{Zn}$ uptake offers interesting research possibilities.

\section{REFERENCES:}

1. Viets, F. G. Jr. and W. L. Lindsay. 1972. Testing soils for zinc, copper, manganese, and iron, pp. 153-172. IN: L. M. Walsh and J. D. Beaton (eds.) Soil Testing and Plant Analysis. Soil Science Society of America, Madison, WI.

2. Bauer, A. and W. L. Lindsay. 1965. The effect of soil temperature on the availability of indigenous soil zinc. Soil Sci. Soc. Am. Proc. 29:413-416

3. Leggett, G. E. and D. T. Westermann. 1986. Effect of corn, sugarbeets, and fallow on zinc availability to subsequent crops. Soil Sci. Soc. Am. J. 50:963968

4. Hislop, J. and I. J. Cooke. 1966. Anion exchange resin as a means of assessing soil phosphate status: a laboratory technique. Soil Sci. 105:8-11

5. Amer, F., D. R. Bouldin, C. A. Black, and F. R. Duke. 1955. Characterization of soil phosphorus by anion exchange resin adsorption and $\mathrm{p}^{32}$ equilibration. Plant and Soil 6:391-408

6. Walmsley, D. and I. S. Cornforth. 1973. Methods of measuring available nutrients in West Indian soils II. Phosphorus. Plant and Soil 39:93-101

7. Moser, U. S., W. H. Sutherland, and C. A. Black. 1959. Evaluationof laboratory indexes of absorption of soil phosphorus by plants:I. Plant and Soil 10:356-374

8. Schnabel, R. R. 1983. Measuring nitrogen leaching with ion exchange resin: a laboratory assessment. Soil Sci. Soc. Am. J. 47:1041-1042

9. Binkley, D. and P. Matson. 1983. Ion exchange resin bag method for assessing forest soil nitrogen availability. Soil Sci. Soc. Am. J. 47:10501052

10. Binkley, D. 1984. Ion exchange resin bags: factors affecting estimates of nitrogen availability. Soil Soc. Am. J. 48:1181-1184

11. Salomon, M. and J. B. Smith. 1957. A comparison of methods for determining extractable soil potassium in fertilizer test plots. Soil Sci. Soc. Am. Proc. 21:222-225 
12. Lindsay, W. L. and W. A. Norvell. 1978. Development of a DTPA soil test for zinc, iron, manganese, and copper. Soil Sci. Soc. Aer. J. 42:421-428.

13. Bio-Rad. 1983. Chelex 100 Chelating Ion Exchange Resin for Analysis, Removal and Recovery of Trace Metals. Bulletin 2020. 